\title{
Correction to: Students' conceptual understanding and attitudes towards technology and user experience before and after use of an ePortfolio
}

\section{Christine Slade ${ }^{1}$ (D) $\cdot$ Terri Downer ${ }^{2}$}

Published online: 17 January 2020

(c) Springer Science+Business Media, LLC, part of Springer Nature 2020

\section{Correction to: Journal of Computing in Higher Education https://doi.org/10.1007/s12528-019-09245-8}

The original published version of this article unfortunately omitted data in Appendices 1 and 2. They were in truncated form. The correct version of the Appendices 1 and 2 is published with this erratum article. The original article has been corrected.

The original article can be found online at https://doi.org/10.1007/s12528-019-09245-8.

Christine Slade

c.slade@uq.edu.au

1 Institute for Teaching and Learning Innovation, The University of Queensland, Rm 319, Level 3, Bldg 17, St Lucia, Brisbane, QLD 4072, Australia

2 School of Nursing, Midwifery and Paramedicine, University of the Sunshine Coast, Sippy Downs, QLD, Australia 


\section{Appendix 1: pre-use student survey}

\section{Student survey of initial expectations of ePortfolios at University of the Sunshine Coast}

The purpose of this survey is to understand student perceptions and expectation project.

Please enter the following information in the box below.

Your middle initial (if you don't have a middle name use " $Z$ "

Month of birth in numerals

First two letters of your mother's first (Christian) name

e.g. Jo Fred Smith is born in February and his mother's name is Carol. His code would be F02Ca

This code is NOT to identify you in any way but allows us to match your pre and post usage survey responses.

Background Information: (Please circle the option/s that best suits your response)

Q1. Age range at time of survey
a) Under 18
b) $18-22$
c) $23-27$
d) $28-35$
e) $36-45$
f) $46-55$
g) $56-65$
h) $66+$

Q2. Gender
a) Male

b) Female

Q3. Role at the University

a) Undergraduate student (full time)

b) Undergraduate student (part-time)

c) Postgraduate student (full time)

d) Postgraduate student (part-time)

Q4. Course Delivery Mode
a) Face-to-face
b) Online
c) Distance
d) A mix of face-to-face and online
e) A mix of face-to-face and distance

Attitudes towards the Use of an ePortfolio

Please circle the option/s that best suit your response. Space is provided for you to write your own answers if requested.

Q1. How do you rate yourself as a computer user?
a) Innovator/designer
b) Early adopter/active user
c) Later adopter/willing user
d) Forced adopter/reluctant user
e) Luddite/loathe technology

Q2. Which statement/s best describe your understanding of an ePortfolio?

a) It is an electronic tool for self-assessment, a place I can record my experiences during my course.

b) It is an electronic version of a paper portfolio

c) It is an electronic filing cabinet filled with examples of my course work.

d) It is a secure electronic repository for me to collect and store evidence of my skills and knowledge attainment

e) It is a place for me to reflect upon my learning journey - where I have come from and where I 'm going - it's about the process of learning

f) It is about evidence of skills, but there's also an opportunity to show the process and to reflect on what this means to me 
g) Other (please add your own definition)

Q3. Have you had any previous experience with ePortfolios?
a) Teaching purposes
b) As a student
c) Personal use
d) Other (please specify)

Q4. How do you feel about the prospect of using an ePortfolio in this course?
a) Enthusiastic
b) Positive
c) Neutral
d) Uncertain
e) Confused
f) Anxious

\section{ePortfolio Use in Your Course}

Please circle the option/s that best suit your response. Space is provided for you to write your own answers if requested.

Q1. What purpose do you expect an ePortfolio to serve in this course?
a) Reflective practice
b) Student learning
c) Assessment
d) Graduate career showcase
e) Accreditation
f) Continuing professional development
g) Employment promotion
h) Performance review evidence
i) Other (please specify)

Q2. Looking at this list again in Q1 above, do you think you will use the ePortfolio for other purposes besides those assigned in this course?

Q3. How often do you anticipate using an ePortfolio?
a) Everyday
b) Three times a week
c) Twice a week
d) Once a week
e) Once a fortnight
f) Once a month
g) Once a semester
h) Not at all 
Q4. What would you like to be able to achieve using an ePortfolio by the end of the year?
a) Create a $\mathrm{CV}$ or resumé
b) Record critical reflections on my learning experiences
c) Demonstrate my learning to others
d) Submit an assessment piece using the ePortfolio
e) Work collaboratively with peers
f) Record evidence of competency
g) Other (please specify)

\section{The Potential Value of Using an ePortfolio}

(Please use your own words in the spaces provided to answer these questions)

Q1. What do you envisage as problems in using ePortfolios?

Q2. What would be the key enablers for you to successfully develop your ePortfolio?

Q3. How do you think developing an ePortfolio could help with accreditation, continuing professional development and employability?

Q4. How do you think using an ePortfolio may help you achieve learning outcomes for the course?

Q5. What sort of support, if any, do you think you need to be successful in using your ePortfolio?

The project team would like to thank you for participating in the survey. 


\section{Appendix 2: post-use student survey}

\section{Student survey post ePortfolio use at University of the Sunshine Coast}

The purpose of this survey is to understand student perceptions and expectations of an ePortfolio after use. Submission of a completed survey implies your consent to participate in this research project.

Please enter the following information in the box below.

Your middle initial (if you don't have a middle name use " $Z$ "

Month of birth in numerals

First two letters of your mother's first (Christian) name

e.g. Jo Fred Smith is born in February and his mother's name is Carol. His code would be F02Ca

This code is NOT to identify you in any way but allows us to match your pre and post-usage survey responses.

Background Information: (Please circle the option/s that best suits your response)

Q1. Age range at time of survey
i) Under 18
j) $18-22$
k) $23-27$
l) $28-35$
m) $36-45$
n) $46-55$
o) $56-65$
p) $66+$

Q2. Gender

c) Male

d) Female

Q3. Role at the University

e) Undergraduate student (full time)

f) Undergraduate student (part-time)

g) Postgraduate student (full time)

h) Postgraduate student (part-time)

i) Other

Q4. Course Delivery Mode
f) Face-to-face
g) Online
h) Distance
i) A mix of face-to-face and online
j) A mix of face-to-face and distance

Attitudes towards the Use of an ePortfolio

Please circle the option/s that best suit your response. Space is provided for you to write your own answers if requested.

Q1. How do you rate yourself as a computer user?
f) Innovator/designer
g) Early adopter/active user
h) Later adopter/willing user
i) Forced adopter/reluctant user
j) Luddite/loathe technology

Q2. Which statement/s best describe your understanding of an ePortfolio now?

h) It is an electronic tool for self-assessment, a place I can record my experiences during my course.

i) It is an electronic version of a paper portfolio

j) It is an electronic filing cabinet filled with examples of my course work.

k) It is a secure electronic repository for me to collect and store evidence of my skills and knowledge attainment

1) It is a place for me to reflect upon my learning journey - where I have come from and where I ' $\mathrm{m}$ going - it's about the process of learning

m) It is about evidence of skills, but there's also an opportunity to show the process and to reflect on what this means to me

n) Other (please add your own definition) 
Q3. Now that you have used an ePortfolio are you...
g) Enthusiastic
h) Positive
i) Neutral
j) Uncertain
k) Confused
1) Anxious

Q4. How easy or hard was it to learn how to use your PebblePad ePortfolio?
a) Very easy
b) Easy
c) Reasonable
d) Hard
e) Very Hard

Why?

Q4. If you are graduating soon will you convert your USC PebblePad account to a personal account so you can keep using your ePortfolio?
a) No
b) Not sure
c) Yes

If 'yes' how do you plan to use your ePortfolio in the future?

\section{ePortfolio Use in Your Course}

Please circle the option/s that best suit your response. Space is provided for you to write your own answers if requested.

Q1. What purpose/s did your ePortfolio serve in this course?
j) Reflective practice
k) Student learning
1) Assessment
m) Graduate career showcase
n) Accreditation
o) Continuing professional development
p) Employment promotion
q) Performance review evidence
r) Other (please specify)

Q2. Looking at this list again in Q1 above, how have you already or will you in the future, use your ePortfolio for other purposes besides those assigned in this course?

Q3. How often did you add to, work in or use your ePortfolio?
i) Everyday
j) Three times a week
k) Twice a week
l) Once a week
m) Once a fortnight
n) Once a month 
o) Once a semester

p) Not at all

Q4. What have you been able to achieve using your ePortfolio?

h) Create a CV or resumé

i) Record critical reflections on my learning experiences

j) Demonstrate my learning to others

k) Submit an assessment piece using the ePortfolio

1) Work collaboratively with peers

m) Record evidence of competency

n) Other (please specify)

\section{ePortfolio Use and USC Graduate Attributes}

The USC Graduate Attributes are the qualities and skills that our University has specifically chosen to give graduates the strategic edge in the workplace and as leaders in the community.

Q5. Which of the following Graduate Attributes have you evidenced in your ePortfolio?
a) Creative and critical thinking
b) Empowered (skills and competency for workforce)
c) Engaged (contribution to work/industry/sector)
d) Ethical (acting with integrity)
e) Knowledgeable (scholarly approach to building disciplinary and interdisciplinary knowledge)
f) Sustainability-focused (responding to ecological, social and economic imperatives)
g) Communication
h) Collaboration
i) Problem solving
j) Organisation
k) Applying technologies
I) Information literacy

The Potential Value of Using an ePortfolio

(Please use your own words in the spaces provided to answer these questions)

Q1. What problems did you encounter when using your ePortfolio?

Q2. What helped you to successfully develop your ePortfolio?

Q3. How do you think developing an ePortfolio will help you with accreditation, continuing professional development and employability? 
Q4. How do you think using an ePortfolio helped you achieve the learning outcomes for the course?

Q5. What sort of support, if any, did you need to be successful in using your ePortfolio?

Thank you for your participation in the survey and assisting the University understand more about using ePortfolios for student learning

Publisher's Note Springer Nature remains neutral with regard to jurisdictional claims in published maps and institutional affiliations. 